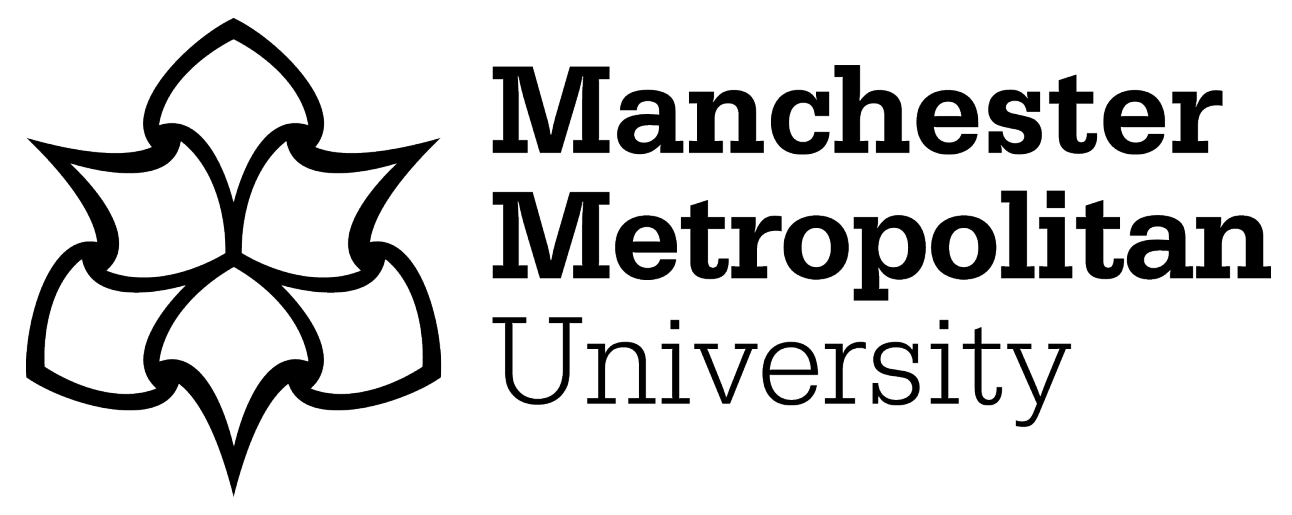

Giladi, P (2018) Hegel's Philosophy and Common Sense. European Legacy, 23 (3). pp. 269-285. ISSN 1084-8770

Downloaded from: https://e-space.mmu.ac.uk/621002/

Publisher: Taylor \& Francis (Routledge)

DOI: https://doi.org/10.1080/10848770.2017.1420285

Please cite the published version 


\section{Philosophy and Common Sense}

My aim in this paper is to argue that whilst Hegel is dismissive of common sense at some level, we should see him as ultimately interested in providing a critical vindication of common sense, ${ }^{i}$ by regarding the philosophical complexities of speculative propositions as providing a properly rational basis for naivety. If the arguments of this paper are successful, then it seems that Hegel's relationship with common sense ${ }^{\mathrm{ii}}$ is more complicated and more interesting than either the long-standing reading of him as disdainful of common sense or the McDowellian reading of him as an ally of laterWittgensteinian philosophical therapy. Hegel is certainly hostile to ordinary consciousness at some level, but we should ultimately see his critique of ordinary consciousness in terms of a nuanced philosophical vindication of common sense.

\section{I}

The traditional reception of Hegelianism has been one which regards Hegelianism to be in clear conflict with common sense. ${ }^{\text {iii }}$ By 'common sense', I mean the philosophically naïve position that we are in direct contact with the objects of perceptual experience, such as chairs, tables, etc. According to this position, which is prominently advocated by John McDowell (1994), our experience of our cognitive environment shows that the world is 'open' or 'transparent', and that because of this phenomenological fact about the mind-world relation, we can reject the "predicament of traditional philosophy ... in which we are supposed to start from some anyway available data of consciousness, and work up to certifying that they actually yield knowledge of the objective world". iv Moreover, the kinds of objects that we experience in our cognitive environment are material, ordinary, finite particulars - these objects have no peculiar metaphysical status, in that they are not emanations of Platonic Forms/modes of an infinite substance/ideas existing in the mind of God. Rather, the objects of human experience are just what we take them to be in our pre-philosophical form of life. One can find evidence for Hegel's apparent contempt for common sense in the following passage from the Science of Logic:

The older metaphysics had in this respect a higher conception of thinking than now passes as the accepted opinion. For it presupposed as its principle that only what is known of things and in things by though is really true in them ... But the reflection of the understanding seized hold of philosophy ... Turned against reason, this understanding behaves in the manner of ordinary common sense, giving credence to the latter's views that truth rests on sensuous reality, that thoughts ae only thoughts ... that only sense perception gives filling and reality to them: that reason, in so far as it abides in and for itself, generates only mental figments. In this self- 
renunciation of the reason, the concept of truth is lost, is restricted to the knowledge of mere subjective truth, of mere appearances ...; knowledge has lapsed into opinion (SL: 21.29-30; 25)

In this passage, Hegel appears to bemoan the growing scientistic culture for turning away from important features of ancient metaphysics, namely commitments to the identity of thought and being and the reality of universals. Instead, according to Hegel, philosophy's 'self-renunciation' has involved adopting the position of ordinary consciousness, which Hegel regards as equivalent to common sense. Here, common sense is being portrayed as effectively a species of nominalism, in that Hegel regards ordinary consciousness as taking what philosophers conceive of as real - universals and laws of nature - to only be 'figments of the brain'. Such a way of interpreting common sense is also found in another passage from the Science of Logic, where Hegel's polemic appears to reach new heights:

The fact is that interest, whether in the content or in the form of the former metaphysics, or in both together, has been lost ... The exoteric teaching of the Kantian philosophy - that the understanding ought not to be allowed to soar above experience, lest the cognitive faculty become a theoretical reason that by itself would beget nothing but mental fancies - this was the justification coming from the scientific camp for renouncing philosophical thought. In support of this popular doctrine was added the cry of alarm of modern pedagogy, that the pressing situation of the time called for attention to immediate needs - that just as in ways of knowledge experience is first, so for skill in public and private life, exercise and practical education are the essential, they alone what is required, while theoretical insight is even harmful. - With science and common sense thus working hand in hand to cause the downfall of metaphysics, the singular spectacle came into view of a cultivated people without metaphysics - like a temple richly ornamented in other respects but without a holy of holies. (SL: 21.5-6; 7-8)

As with the previous passage I discussed, Hegel appears to portray common sense in a manner suggesting that it is diametrically opposed to speculative philosophy: common sense is anti-metaphysics, whereas speculative philosophy is pro-metaphysics; common sense is opposed to speculative cognition; common sense prioritises practical skills over theoretical insights, whereas speculative philosophy does not denigrate theoretical insight at all. ${ }^{v}$ Having detailed the basics of Hegel's portrayal of common sense, I would now like to focus on two specific dimensions of Hegel's understanding of common sense.

Firstly, whilst Hegel's claim that ordinary consciousness aims to bring about the downfall of metaphysics may seem somewhat excessive, I think he is right to suppose that common sense is at the very least suspicious of and not all that keen on 
metaphysics. For, two of the most prominent advocates of common sense in the $20^{\text {th }}$ century, namely Wittgenstein and McDowell, have been especially keen on avoiding any substantive metaphysical commitments. Focusing on McDowell rather than Wittgenstein, one finds that according to McDowell the objects of perceptual experience are in fact exactly what we take them to be in a philosophically naive way: they are finite, material objects. However, whilst McDowell appears to regard metaphysical questions over the objects of perceptual experience to yield no answer apart from the philosophically naïve attitude to them, Hegel disagrees with McDowell's 'metaphysical' commitments. To see the way in which Hegel disagrees with McDowell, let us consider the following passage:

The claim that the finite is an idealisation defines idealism. The idealism of philosophy consists in nothing else than in the recognition that the finite is not truly an existent. Every philosophy is essentially idealism or at least has idealism for its principle, and the question then is only how far this principle is carried out. ( $S L$ : $21.142 ; 124)$

Much in this passage would no doubt raise some eyebrows in contemporary analytic circles, particularly the idea that all philosophy is 'idealism': however, what this means is not that reality is mental in a Berkeleyan sense, rather it means that if someone hopes to present a philosophical view of reality, then one must be prepared to regard ordinary objects (finite particulars) as relying on more fundamental things that serve as their 'ground'. For Hegel, because the objects of perceptual experience are finite, their finitude reveals a metaphysical limitation of ordinary objects - a metaphysical limitation that McDowell would not be willing to accept. Therefore, as Brady Bowman correctly notes, this marks an important difference between Hegel's metaphysical idealism and McDowell's realism. ${ }^{\mathrm{vi}}$

Secondly, another feature of common sense that both McDowell's laterWittgensteinian brand of philosophical quietism and Hegel's portrayal of ordinary consciousness share is the idea that common sense stands in contrast with the complexities and complicatedness of philosophical consciousness. Ordinary consciousness, just as with Wittgenstein's and McDowell's respective metaphilosophical positions, is interested in making sure that we stick to a pre-philosophical form of life and avoid the perils of philosophical speculation. To put this simply: ordinary consciousness and McDowellian quietism aim "to vindicate common sense, to put us 
back in touch with tables, cats and other people ..." vii However, it is on this particular issue that there seems to be clear differences between McDowell's and Hegel's metaphilosophical commitments. As Robert Stern writes, "Hegel wants much more - to vindicate a kind of conception of philosophy that Kant had thought was impossible, and which would also appear to have no place in McDowell's therapeutic, lateWittgensteinian outlook", viii

The conception of philosophy that Hegel aims to vindicate, given the passages we have considered, would appear to be an Aristotelian kind, where philosophers are fundamentally concerned with the science of being-qua-being, as opposed to the Kantian project of only focusing on the science of transcendental judgements, and as opposed to the later-Wittgensteinian idea of only focusing on the proper use of ordinary language. ${ }^{\text {ix }}$ Perhaps what is the best example of the contrast between Hegelian metaphilosophy and McDowell's metaphilosophy concerns their respective attitudes to sceptical problematics: for Hegel, philosophers must take the sceptical challenges of ancient scepticism with the utmost seriousness and aim to directly reject sceptical arguments. ${ }^{\mathrm{x}}$ To progress through the various forms of consciousness in the Phenomenology of Spirit where the journey of the phenomenological subject is "the pathway of despair" necessarily involves engaging with sceptical problematics which appear to threaten our most fundamental epistemic, moral and even existential attitudes to ourselves, our fellow man, and our cognitive environment as a whole.

Unless we take the threat of scepticism seriously and "tarry with the negative", then, according to Hegel, we can never have a rational grip on the world and thus never be at home in the world. McDowell, however, has a noticeably different attitude to sceptical questions: "The aim here is not to answer sceptical questions, but to begin to see how it might be intellectually responsible to ignore them, to treat them as unreal, in the way that common sense has always wanted to". ${ }^{x i}$

Now, I have argued elsewhere that both Hegel and Wittgenstein are committed to a quietist conception of philosophy, where the aim is to dissolve philosophical problems and return us to a state of intellectual peace from a state of intellectual disquietude. However, a crucial difference between Hegelian and Wittgensteinian quietism lies in how Hegel thinks the source of intellectual disquietude is poor philosophical frameworks and reflecting purely from the standpoint of common sense, whereas Wittgenstein thinks that the source of intellectual disquietude comes from philosophical speculation simpliciter. 
Correspondingly, both Hegel and Wittgenstein stand in contrast to one another in terms of what philosophical therapy to administer to cure our maladies intellectuelles. ${ }^{\text {xii }}$ For Hegel, the cure is speculative philosophy; for Wittgenstein, it is a move to an unreflective pre-philosophical form of life. In order to clearly explain the ways in which Hegel's quietism opposes common sense, I would like to draw attention to the following two passages:

The more that conventional opinion holds that the opposition between the true and the false is itself fixed and set, the more that it customarily expects to find itself in either agreement or in contradiction with any given philosophical system, and, if so, then in any explanation of such a system, the more it will merely see the one or the other. It does not comprehend the diversity of philosophical systems as the progressive development of truth as much as it sees merely contradiction within that diversity. The bud disappears when the blossom breaks through, and one might say that the former is refuted by the latter. Likewise, by virtue of the fruit, the blossom itself may be declared to be a false existence of the plant, since the fruit emerges as the blossom's truth as it comes to replace the blossom itself ... However, at the same time their fluid nature makes them into moments of an organic unity within which they are not only not in conflict with each other. Rather, one is equally as necessary as the other, and it is this equal necessity which alone constitutes the life of the whole. However, in part, contradiction with regard to a philosophical system does not usually comprehend itself in this way, and, in part, the consciousness which apprehends the contradiction generally neither knows how to free the contradiction from its one-sidedness, nor how to sustain it as freestanding by taking cognizance of its reciprocally necessary moments, which themselves take shape as conflicts and as apparent incompatibilities. (PS: §2)

For Hegel, an important symptom of philosophical disquietude is how we tend to regard certain ideas to be fundamentally irreconcilable with one another. And we think in that way due to having a non-dialectical understanding of negation. Our ordinary (or natural) understanding of negation is one which sees the negation of a position as the complete obliteration of that position. This, in turn, serves as the grounds for the strength of the Law of Non-Contradiction. However, whilst our ordinary understanding of negation has both plausibility and practical value, the problem with this framework is not that the framework is false or incoherent, but rather that the framework cannot adequately make sense of the notion of development and growth. Hegel's concern, then, with negation is with the philosophical aporias we run into when we reflect on the history of philosophical enquiry and how we try to understand the movements from one philosophical tradition to the next. 
We remain paralysed by these kinds of aporias, if we reflect only from the ordinary perspective of negation. Therefore, the remedy for this is to improve our philosophical understanding. For Hegel, specifically, one way of successfully accomplishing such a task is by distinguishing between reason (Vernunft) and understanding (Verstand). Unlike Kant, Hegel does not claim that "these terms ... designate completely independent functions or faculties. Reason is simply the necessary result of the immanent movement of the understanding" xiii In other words, reason is a "form of holistic explanation, which shows how all finite things are parts of a wider whole". xiv

For Hegel, the principal advantage of drawing this distinction between reason and understanding is that we can be in a position to not be wrapped up in the various dualisms which are the inevitable consequence of reflecting only from the perspective of understanding, i.e. purely analytical forms of reflection. What reason provides consciousness with is the means to avoid the pitfalls of dualisms and the problems of analysis by thinking dialectically, i.e. by drawing distinctions yet establishing interconnectedness to a whole. Turning now to Hegel's lectures, we can find a similar point being made against ordinary consciousness:

\begin{abstract}
What man seeks in this situation, ensnared here as he is in finitude on every side, is the region of a higher, more substantial, truth, in which all oppositions and contradictions in the finite can find their final resolution, and freedom its full satisfaction ... The highest truth, truth as such, is the resolution of the highest opposition and contradiction. In it validity and power are swept away from the opposition between freedom and necessity, between spirit and nature, between knowledge and its object, between law and impulse, from opposition and contradiction as such, whatever forms they make take. Their validity and power as opposition and contradiction is gone ... The ordinary consciousness, on the other hand, cannot extricate itself from this opposition and either remains despairingly in contradiction or else casts it aside and helps itself in some other way. But philosophy enters into the heart of the self-contradictory characteristics, knows them in their essential nature, i.e. as in their one-sidedness not absolute but selfdissolving, and it sets them in the harmony and unity which is truth. To grasp this Concept is the task of philosophy. ( $L A$ I: 99-100)
\end{abstract}

The arguments Hegel gives in this engaging passage - namely that the task of philosophy is to lead our ways of understanding all aspects of our world away from purely dualistic and oppositional ways of thinking, and to enable us to reflect on the intelligibility of both difference and unity in our world - serve as a powerful critique of quietist strategies that aim to provide philosophical cures by means of effectively ignoring the philosophical nature of certain problematics. For Hegel, if we are to achieve intellectual peace and if 
we are to flourish as human beings, we must tarry with our world and push ourselves to find the best philosophical theory that enables us to be at home in the world.

If what I have argued has been successful, then it would seem that Hegel can only be seen as a great foe of common sense. However, whilst I admit that there is good reason to think that Hegel's metaphysics of finitude, his insistence on the legitimacy and necessity of speculative metaphysics, and his therapeutic critique of ordinary consciousness appear to leave almost no room to suppose Hegel could be allied with common sense, in what follows, I shall argue that that Hegel should in fact be read as aiming to vindicate common sense in rather ingenious way.

In the first section of this paper, I offered some reasons to think that Hegel and common-sense realism/naivety should be regarded as in conflict with one another. Such a way of understanding Hegel's relationship with common-sense realism finds notable support in the work of Michael Friedman, who writes:

It is characteristic of post-Kantian absolute idealism (and, indeed, of virtually all post-Kantian philosophy) to reject Kant's dualistic conception of our rational faculties as divided between pure sensibility on the one side and pure understanding on the other ... Moreover, it is also characteristic of post-Kantian absolute idealism to take the Kantian faculty of reason rather than the Kantian faculty of understanding as the model for rationality as such - and, indeed, to take the rational freedom required by morality as the model for all rationality. The combined effect of these two moves, then, is a tendency to distance rational thought from sensible experience and to minimise the empiricist elements in Kant's own conception. ${ }^{\mathrm{xv}}$

Friedman offers here another argument to regard Hegel as fundamentally opposed to common-sense realism. His basic claim is that we should see the transition from Kant to Hegel - the transition from transcendental idealism to absolute idealism - in terms of a gradual abandoning of any empiricist - i.e. realist - elements of Kantianism. As such, taking into consideration the new apparatus of Hegel's logic, speculative propositions, and the dialectical method, coupled with Hegel's apparently anti-empiricist philosophical stance, we can only really conclude that Hegel and common-sense realism/naivety are foes.

However, I am not convinced that Friedman's portrayal of Hegel is completely accurate. Certainly, Friedman is correct to claim that what is characteristic of post- 
Kantian absolute idealism is in part a critique of the empiricism one finds propagated by Locke. The question now is whether Hegel's speculative critique of empiricism actually amounts to a philosophical opposition to empiricism. To answer this, I would like to draw attention to the following passage from Hegel's lectures on Locke:

\begin{abstract}
As to the question in point we must in the first place say that it is true that man commences with experience if he desires to arrive at thought. Everything is experienced, not merely what is sensuous, but also what excites and stimulates my mind. Consciousness thus undoubtedly obtains all conceptions and Notions from experience and in experience; the only question is what we understand by experience. In a usual way when this is spoken of the idea of nothing particular is conveyed; we speak of it as of something quite well known. But experience is nothing more than the form of objectivity ... Experience thus signifies immediate knowledge, perception, i.e. I myself must have and be something, and the consciousness of what I have and am is experience. Now there is no question as to this, that whatever we know, of whatever kind it may be, must be experienced, that rests in the conception of the thing. It is absurd to say that one knows anything which is not in experience. (LHP III: 303)
\end{abstract}

Hegel's claims in this passage appear to amount to an endorsement of empiricism - or at the very least, an endorsement of its most basic doctrine. But this now only seems to confuse the issue, because Hegel is judged to be critical of empiricism yet clearly endorses its essential commitment. We remain confused, though, only if we take Hegel's criticisms of empiricism to signify a philosophical dismissal of empiricism. Instead of seeing Hegel as the bete noire of empiricism, I think there is better reason to think of him as offering an internal critique of it, on the grounds that the kind of empiricism advocated by Locke and Hume falls short of being an adequate conception of empiricism. For, in the following passage from the Lectures on the History of Philosophy, Hegel both states his negative attitude to early modern empiricism and his commitment to reforming the doctrine to make it fit for purpose:

The empirical is not only mere observing, hearing, feeling, perceiving particulars, but it also essentially consists in finding species, universals and laws. (LHP III: 176)

For Hegel, the realm of experience does not just include particulars, but crucially universals and nomological properties as well. The motivation for widening the scope of the empirical, to a large extent, lies in Hegel's underlying dissatisfaction with certain aspects of Enlightenment philosophy and natural science. Hegel's main criticism is that particular features of Enlightenment philosophy and natural science have resulted in a 
disenchantment of nature. ${ }^{\text {xvi }}$ This disenchantment is caused by an impoverished understanding of how our minds work, and an impoverished understanding of the content of experience.

Under Hegel's anti-nominalist and more robust account of the world of experience, if we constrict our conception of experience to very narrow and analytical standards, then our knowledge claims are restricted to the following kinds of propositions, as Hegel writes, "here is my lighter and there is my tobacco tin" (LHP III: 444-5): the problem with the proposition is not so much the content, namely the lighter and the tobacco tin, but rather the way in which we represent the content, as bringing in no attempted explanation or understanding of their relation to one another. The framework for understanding objects of experience is restricted to the level of ordinary consciousness, which means that the only kinds of judgement we can make about the world of experience are thin judgements which express atomistic separation and only some artificial kind of unity - viz., 'here', 'there', and the conjunct 'and'. The thinness, then, consists in failing to account for the interconnectedness yet basic difference between objects. Hegel sees his absolute idealism as an expression of philosophical consciousness, precisely because it aims to capture both the inherent unity of all finite things whilst respecting the basic difference between all finite things. As he writes in the Difference essay:

To cancel established oppositions is the sole interest of reason. But this interest does not mean that it is opposed to opposition and limitation in general; for necessary opposition is one factor of life, which forms itself by eternally opposing itself, and in the highest liveliness totality is possible only through restoration from the deepest fission. (II 21-2/91)

In operating under an epistemic framework which accounts for both unity and difference (e.g. subject-object-identity and subject-object-non-identity), Hegel thinks we can do justice to the richness of our world and therefore how we can have a rich conception of experience. The question now is whether there is reason to suppose that one can take Hegel's internal critique of empiricism - where Hegel criticises empiricism in order to vindicate empiricism - to signify an internal critique of common sense.

Prima facie, it seems difficult to propose that Hegel's critique of common sense can and should be construed as a vindication of common sense. For, Hegel's position on nature and the finite is not easy to arrive at, as the near-entirety of his speculative system 
is required[' to understand the possibility of a determinate, ontologically complex and rationally structured order of things. It would seem then that one can only construe Hegel as denying naivety. This now potentially raises a problem for philosophers such as Ken Westphal, ${ }^{\text {xvii }}$ Stern, and Bowman, who are all committed to Hegel's epistemological realism: the objects of cognition are intelligibly structured and their intelligibility is determined independently of any cognitive activity on our part. How can we make sense of Hegel's commitment to epistemological realism, which is central to ordinary consciousness, and Hegel's commitment to the superiority of speculative idealism and philosophical consciousness?

We can make sense of this by first noting that Hegel's commitment to epistemological realism and his commitment to speculative idealism do not make him out to be opposed to common sense in a special sense. Hegel's dissatisfaction with common-sense realism is with common-sense realism's conception of the metaphysics of finite objects. He agrees with the phenomenological and epistemological claims that the world is open and intelligible, but he disagrees with the particular metaphysical understanding of finitude from the perspective of ordinary consciousness.

What is central to Hegel's dispute with the metaphysics of finitude from the perspective of ordinary consciousness is that such metaphysics is not the right kind of metaphysical articulation. Hegel's idealist metaphysics of finitude, crucially, does not comprise of a Berkeleyan claim that finite objects require perceiving minds to exist, ${ }^{\text {xviii }}$ nor does it comprise of a Kantian claim that finite objects require perceiving minds to exist for us, xix but rather comprises of the claim that finite particulars are not 'ultimate' or 'absolute' or 'self-explanatory'. As Hegel writes:

For our ordinary consciousness (i.e., the consciousness at the level of senseperception and understanding) the objects that it knows count as self-standing and self-founded in their isolation from one another, their mutual dependence on one another is regarded as something external to the object, and not as belonging to their nature. It must certainly be maintained against this that the objects of which we have immediate knowledge are mere appearances, i.e., they do not have the ground of their being within themselves, but within something else ... [T] he true situation is that the things of which we have immediate knowledge are mere appearances ... and that the proper determination of these things, which are in this sense 'finite' consists in having the ground of their being not within themselves but in the universal divine Idea. (EL: $\$ 45 Z, 88-9)$ 
Ordinary consciousness treats finite particulars as 'ultimate' or 'absolute' or 'selfexplanatory', simply because the framework of ordinary consciousness refuses to go beyond what is immediately given to us in perception. However, Hegel's point here is that if we are to genuinely think philosophically, we must be prepared to reject the metaphysical supposition that finite particulars are the only things which exist, that finite particulars can be adequately made sense of as atomistic and non-holistic entities, and the epistemic supposition that explanation is restricted to the standards of ordinary consciousness: the intellectual demand on rational agents, then, is one which aims to accommodate the reality of particulars and maintain their dependence on more 'real' structures, such as universals, in order to do justice to both the nature of determinate being and the standards of philosophical consciousness. This is why, for Hegel, a move from ordinary consciousness to philosophical consciousness consists in recognising that 'the finite is not truly an existent - i.e. that finite objects are not absolute entities, but rather entities that depend on relations, one of which, to use Paolo Diego Bubbio's terminology, is 'mediate objectivity', “... an ongoing process of mediation between subject and object which is always already in place...". ${ }^{x x}$ Rather than have the world in view in terms of reality comprising a rhapsodic scene of a loosely connected set of objects, ${ }^{\mathrm{xxi}}$ we ought to conceive of Being as comprising a complex and interconnected whole in which the finite members are dialectically related.

In response to my conceptual realist interpretation of Hegel, Pippin can object by arguing that

\begin{abstract}
such an interpretation still makes Hegel a fundamentally pre-critical philosopher, committed to the basic rationalist dream shattered by Kant. Hegel's many remarks about "completing" the Kantian revolution, or celebrating the modern "principles of subjectivity," are very hard to understand on such a reading. It is as if Hegel simply missed the point, the massive, unavoidable point, of the Critique of Pure Reason". xxii Thereafter, instead of an a priori science of substance, a science of "how the world must be' ... a putative philosophical science was directed to the topic of how any subject must 'for itself' take or construe or judge the world to be". xxiii
\end{abstract}

However, the implication that Hegel must be a philosopher engaging in a project that is either continuous with transcendental idealism or one which merely aims to tweak certain elements of Kant's transcendentalism to make sure that metaphysics is properly laid to rest does not hold, due to the oversimplification of the concept of postKantianism: the essence of post-Kantianism is not simply an endorsement of replacing 
the a priori science of being-qua-being with the a priori science of transcendental judgement - which one can take to be the spirit of the Copernican turn in philosophy - but rather a commitment to how traditional metaphysics can be revised so as to make metaphysics tout court respectable and worth pursuing once more. What I mean by this is that, for Hegel, Kant's devastation of dogmatic metaphysics did not signify the destruction of metaphysics tout court, but rather the analysis and systematic undermining of traditional rationalism opened the path to an approach to the problems of philosophy that is totally critical. The dialectical shift from Leibnizian-Wolffian rationalist metaphysics to transcendental idealism, for Hegel, culminates with the clues for seeing how both metaphysics and transcendental philosophy can now be transformed into speculative philosophy. Understood in this way, Hegel's idealist metaphysics illustrates that "metaphysics after Kant is a science of being as being thought". xxiv

Secondly, we can make also sense of Hegel's commitment to epistemological realism and Hegel's commitment to the superiority of speculative idealism and philosophical consciousness, by pointing to how we ought to understand Hegel's claim that philosophical consciousness is superior to ordinary consciousness. Instead of seeing this in terms of a crude notion that philosophy is right and common sense is wrong, I think we should understand the putative superiority of philosophy over ordinary consciousness in terms of McDowell's notion of responsiveness to reasons. As I read Hegel, the advantage that philosophy is alleged to have over ordinary consciousness is philosophical consciousness's ability to self-critically reflect on its various criteria for understanding the mind-world relation. In other words, philosophical consciousness is able to have access to reasons that provide a rational justification for certain beliefs, to the extent that by doing so, philosophical consciousness "raises the question under what conditions we would be able to articulate the presumptuous direction of realist thought". ${ }^{x v}$ The limitation that ordinary consciousness has, which is perhaps made more debilitating by it lacking dialectical logical categories, is its structural inability to provide rational articulations of its own realist commitments. For, ordinary consciousness, by virtue of definition, cannot be self-consciously reflective about whether or not its conception of the mind-world relation is in fact rationally justified. It lacks the necessary responsiveness to reasons to make it a critical rather than dogmatic position. Perhaps another way of expressing this can be by claiming that philosophical consciousness can make explicit the realist commitments 
ordinary consciousness takes implicitly. This is what I take to be the central claim of this passage from Hegel:

... [T] he naive way of proceeding, which, being still unconscious of the antithesis of thinking within and against itself, contains the belief that truth is [re]cognised, and what the objects genuinely are is brought before consciousness, through thinking about them. In this belief, thinking goes straight to the objects; it reproduces the content of sense-experience and intuition out of itself, as a content of thought, and is satisfied with this as the truth ... [T] he daily doing and dealing of consciousness lives in this belief. Because it is unconscious of its antithesis, this thinking can, in respect of its basic import, equally well be authentic speculative philosophising; but it can also dwell within finite thought-determinations, i.e. within the still unresolved antithesis. $(E L: \S 26-7,65)$

To see how this works, I would like to present the following taxonomy:

1. Common Sense/Ordinary Consciousness: (a) the world is a phenomenologically robust cognitive environment; ${ }^{x x v i}$ (b) scepticism can be dismissed without any real engagement with scepticism.

2. Speculative Philosophy/Philosophical Consciousness: (a) the world is a phenomenologically robust cognitive environment; (b) ${ }^{*}$ scepticism can be dismissed.

Both common sense and speculative philosophy are committed to the idea that the world is a phenomenologically robust cognitive environment, in that both positions take the world to be composed of knowable substances governed by causal laws. However, the crucial difference between common sense and speculative philosophy lies in how they respectively arrive at this conclusion. Ordinary consciousness will appeal either to a prephilosophical standpoint akin to 'open your eyes and just look at how rich and detailed the world is' or to the results of empirical and natural science that confirm that the world is rich and detailed. Philosophical consciousness will appeal to how this determinate and ontologically complex and rationally ordered environment is thus-and-so given how it is constituted by (i) conceptual structures and (ii) concrete universals:

Regarding (i), an important feature of Hegel's discussion of Sense-Certainty ${ }^{x x v i i}$ is Hegel's aim to show how the necessary conditions for the possibility of language render the position of Sense-Certainty incoherent. For, Hegel's target in the opening chapter of the Phenomenology is someone who thinks that reference is possible by virtue of providing ostensive definitions. ${ }^{\text {xxviii }}$ In other words, according to the Sense-Certainty theorist, I am 
able to pick out individual objects and label such objects as those objects simply by pointing to those and only using ostensive indexicals. As Robert Pippin writes, “... the goal [of Hegel's argument] is obviously to demonstrate that even the simplest form of demonstrative reference would not be possible without some describing capacity, a capacity that requires descriptive terms or predicates ... not merely deictic expressions and atomic objects". xxix To see how this works, let us briefly consider Hegel's argument: according to the sense-certainty theorist, I can pick out and refer to an individual object by pointing to it and dubbing it the here-and-now. For sense-certainty, here-and-now is meant to capture a unique feature of an object and thus enable me to refer to that individual object. However, Hegel proceeds to argue that being here-and-now is far from unique to the object, as different times and places can come to be here-and-now, and thus so can different things. Sense-certainty, therefore, has failed to properly refer to this particular object by virtue of picking out its singular individuality, because all that sensecertainty has been able to do is to pick out a property that can belong to many individuals, a property which is universal. ${ }^{\mathrm{xx}}$ Not only that, the ultimate problem with sense-certainty's commitment to referring to individual objects without reference to concepts - what Hegel calls apprehension - is that the non-conceptual 'describing' capacities fail to refer simpliciter, because what we discover in the dialectic of sensecertainty is that concepts and a holistic logico-linguistic framework ${ }^{\text {xxxi }}$ are necessary conditions for the possibility of reference.

This discovery means that, qua philosophical consciousness, one realises that in saying 'The rose is red', the semantic content cannot be given independently of an account of the kinds of inferential commitments one must make in the activity of assertion: to be able to pick out this particular rose as being this particular colour, one must know that the rose cannot be yellow or blue, etc. Not only that, for Hegel, what makes 'The rose is red' a judgement rather than just a saying, is the role determinate negation plays in providing the conditions under which picking out an individual object is mediated through contrasting it with other possibilities of predication and other objects. ${ }^{\text {xxxii }}$ Why, then, non-conceptual capacities are dismissed by Hegel is precisely because they fail to provide the conditions for successfully picking out an individual object, since apprehension is entirely indeterminate.

Regarding (ii), for Hegel, we can best make sense of individual finite objects by construing them in terms of the logico-metaphysical relations of concrete universality. 
The concrete universal is understood to involve a dialectical relationship between universality, individuality and particularity. Crucially, this is what distinguishes the concrete universal from the abstract universal; the abstract universal is not dialectically structured, hence why Hegel regards it as "isolated" and "imperfect". Its isolation and imperfection consist in how the abstract universal is the result of a poor way of relating the categories of universality, particularity, and individuality. Abstract universality is opposed to the particular and the individual. ${ }^{\text {xxiii }}$ Concrete universality is not opposed to the particular and the individual. Furthermore, the concrete universal is the communion of universality, particularity and individuality. And, as such, is the proper conceptualisation of the relationship between these three categories. The significance of this can be found by discussing Hegel's analysis of 'Caius is a man', which can shed light on what exactly a concrete universal is for Hegel.

'Caius is a man': 'Being human' is an essential property of Caius. "The single human is what he is in particular, only insofar as he is, first of all, human as such, and within the universal; and this universal is not just something over and above the other abstract qualities or mere determinations of reflection, but is rather what permeates and includes within itself everything particular". $(E L: \S 175,253)$ Caius can only be a particular individual man if he is a man. And Caius cannot be an indeterminate man, he must be a determinate instantiation of man.

'Caius is a man' is the kind of judgement that arrives at the dialectical relationship between the categories of universality, particularity, and individuality. The universal is now concrete, principally because it is what an individual is, in that an individual is an instantiation of that kind of universal: Caius is an instantiation of man. By exemplifying the property of being a man, even though Caius is distinct from other individual exemplifications of man, Caius is the individual that he is, while his being a man is also required for and compatible with the particular determinations that make him the specific man he is.

Speculative philosophy, therefore, has as its function the need to make explicit - i.e. provide speculative/rational/critical articulation - what common sense takes implicitly. In this sense, philosophical consciousness is more responsive to reasons than ordinary consciousness. 
III

With regard to the issue of settling scepticism, we have seen that Hegel thinks we really need to tarry with scepticism in order to dismiss it, whereas the philosophically naive disposition is to just ignore the defeaters that give rise to sceptical problematics as soon as the sceptic puts them forward. I take Hegel to be so concerned about providing a rational undermining of scepticism, because he thinks that ordinary consciousness's refusal to recognise the need to acknowledge and then (dialectically) show that the grounds for motivating scepticism are illegitimate prevents ordinary consciousness from genuinely attaining a sense of intellectual peace. Given this, whilst the following passage gives one reason to see Hegel denying common sense, I think there is more compelling reason to take him to want to vindicate it by providing a critical foundation for its commitments:

\begin{abstract}
When a man asks for a royal road to science, no more convenient and comfortable way can be mentioned to him than to put his trust in "healthy common sense" ... But spiritual elation in the eternal, the sacred, the infinite, moves along the highway of truth in the robes of the high priests road that, from the first, is itself immediate being in its innermost, the inspiration of profound and original ideas and flashes of elevated thought. All the same, those depths do not yet reveal the well-spring of inner reality ... True thoughts and scientific insight can only be won by the labour of the notion. Conceptions alone can produce universality in the knowing process. This universality is critically developed and completely finished knowledge. It is not the common indefiniteness and inadequacy of ordinary intelligence ... It is truth which has successfully reached its own inherent native form. It is this universality which is capable of being the property of every self-conscious reason. $(P S: \S 70)$
\end{abstract}

Aside from some of the Hegelian rhetoric in this section from the Phenomenology, Hegel conceptualises the distinction between common sense/ordinary consciousness and speculative philosophy/philosophical consciousness in terms of common sense being 'inadequate' and unreflective, whereas speculative philosophy is fully actualised rationality. This does not mean that ordinary consciousness is fundamentally wrong or misguided in how it represents the world; rather it means that ordinary consciousness is not sufficiently responsive to reasons. Because it is not sufficiently sensitive to reasons, common sense is judged by Hegel to provide for us only potential rational satisfaction, whilst speculative philosophy, because it 'labours with the notion' - i.e. philosophical consciousness is dialectically sensitive - provides actual rational satisfaction. ${ }^{\text {xxiv }}$ 
Having said this, though, it seems difficult to maintain the proposal that Hegel's critique of common sense amounts to aiming to provide a speculative vindication of the commitments of common sense when we consider Hegel's caustic rebuke of ordinary consciousness in his essay 'Who Thinks Abstractly?'. Here, Hegel launches a scathing attack on ordinary consciousness's claims that its epistemic standards favour concrete thinking, and that speculative philosophy indulges in purely abstract thinking. As he writes:

\begin{abstract}
Who thinks abstractly? The uneducated, not the educated ... A murderer is led to the place of execution. For the common populace he is nothing but a murderer. Ladies perhaps remark that he is a strong, handsome, interesting man. The populace finds this remark terrible: What? A murderer handsome? How can one think so wickedly and call a murderer handsome; no doubt, you yourselves are something not much better! This is the corruption of morals that is prevalent in the upper classes, a priest may add, knowing the bottom of things and human hearts. One who knows men traces the development of the criminal's mind: he finds in his history, in his education, a bad family relationship between his father and mother, some tremendous harshness after this human being had done some minor wrong, so he became embittered against the social order - a first reaction to this that in effect expelled him and henceforth did not make it possible for him to preserve himself except through crime. - There may be people who will say when they hear such things: he wants to excuse this murderer! After all I remember how in my youth I heard a mayor lament that writers of books were going too far and sought to extirpate Christianity and righteousness altogether ...

This is abstract thinking: to see nothing in the murderer except the abstract fact that he is a murderer, and to annul all other human essence in him with this simple quality. ${ }^{\mathrm{xxx}}$
\end{abstract}

According to Hegel, the explanation for why ordinary consciousness, rather than philosophical consciousness, thinks abstractly consists in that the logical framework and conceptual structure of ordinary consciousness are both limited. Their epistemic shortcomings are due to not being able to make properly well-informed judgements and to being incapable of seeing how some predicates can be grouped together in a consistent manner. ${ }^{\text {xxxi }}$ In the example that Hegel gives, ordinary consciousness is guilty of abstract thinking, insofar as its understanding of the criminal is not sufficiently reflective. Unlike the more critically-minded enquiry, ordinary consciousness does not delve into criminology, in an effort to properly understand why the criminal did what they did and then determine what is the appropriate judgement to make. Furthermore, Hegel suggests that there is a considerable risk that ordinary consciousness, given its abstract epistemic standards, can conflate 'wanting to critically understand the criminal' with 'with wanting to excuse the criminal', which would amount to a category error. 
Taking into account Hegel's treatment of ordinary consciousness in this essay - that ordinary consciousness is not a sufficiently critical mode of reflection - it seems rather problematic to maintain the view that Hegel aims to provide a speculative vindication of common sense / actualise what common sense potentially understands.

However, in response, I think we can consistently claim that Hegel's treatment of common sense has both a negative and positive aspect to it, if we do not consider each part of his reflections on common sense independently of one another. After all, because Hegel characteristically adopts a dialectical method, he invites us to sublate various concepts, in an effort to arrive at a fully critical and complete understanding of those very concepts. As with, to use just one example from Hegel's philosophical system, his treatment of universals, ordinary consciousness is sublated in how Hegel invites us to see how common sense and its determinate negation dialectically interrelate. Just as our reflections on realism about universals involve moving from an abstract conception of universality through a nominalism about universality and ending with a concrete conception of universality, we move from seeing philosophical consciousness and ordinary consciousness in square conflict with one another through to seeing them as allies and then finally seeing speculative philosophy as critically vindicating ordinary consciousness.

Of course, given that ordinary consciousness is being sublated by Hegel, some features of ordinary consciousness will be committed to the flames, while other features of common sense will be preserved and raised higher by dialectical critique. What is crucial, though, is that we conceive of this critical vindication neither in terms of a basic return to a pre-philosophical form of life nor in terms of a reluctant acceptance of the various commitments of common-sense realism: as we have seen, Hegel thinks that the only way to properly conclude that the world is fundamentally intelligible and that it is a phenomenologically robust cognitive environment is by developing the intricate and nuanced arguments of speculative idealism. These arguments are not available to ordinary consciousness, given the difference between the respective frameworks of common sense and speculative philosophy, but nor are these arguments ones which force philosophical consciousness to accept aspects of ordinary consciousness. For, under Hegel's account, once we arrive at a speculative understanding of the mind-world relation, then there is a harmonious relationship between common sense and speculative philosophy, in that the philosopher has provided a critical ground for the commitments of 
common-sense realism and makes explicit what ordinary consciousness had taken implicitly.

However, is this not true for every epistemological position that Hegel considers? In other words, is all what I have argued here just an application of Hegel's fundamental principle of Aufhebung, which we see at work everywhere in Hegel's system? Should we apply the principle of Aufhebung to common sense (contra McDowell), as we do to every other aspect of Hegel's philosophy? Or is there something philosophically special in the vindication of common sense, unlike apparently similar applications of the Aufhebung principle?

In response, I would argue that while we should apply the principle of Aufhebung to common sense, we should, at the same time, also insist that there is something philosophically special in the vindication of common sense by speculative idealism, unlike apparently similar applications of the Aufhebung principle. To see why, I would like to consider the subtle ways in which the vindication of common sense differs from Hegel's sublation of the concept of Being and Hegel's sublation of the concept of unity: in the opening stages of the Science of Logic, Hegel makes use of Spinoza's 'All Determination is Negation' in an effort to reject Eleatic monism: ${ }^{x x x v i i}$ the negation that accompanies determination is a necessary condition for the possibility of being in any genuine sense. In other words, Hegel claims that if anything is to be, then it must have determination and so negation. His argument can be understood as follows: for anything to be more than just a completely formal and abstract pure being, ${ }^{\text {xxxviii }}$ which for Hegel is the same as nothingness, ${ }^{\text {xxix }}$ there must be some kind of determination. Such determination must involve some negation. ${ }^{x 1}$

On the socio-political front, Eleatic monism would inevitably be the theoretical concomitant of a rather eerie form of conservatism. The challenge, therefore, for Hegel's social theory is to articulate a notion of wholeness which does not bring about or facilitate social totalitarianism. According to Hegel, the state is conceived of as a whole, one whose structure is constituted by mediated unity: in contrast to Attic ethical life, the individual now no longer defines themselves as purely a functioning part of the community; and in contrast to modern ethical life, typified by Abstract Right (personal freedom) and Morality (moral freedom), the individual does not regard their subjectivity to define themselves as fundamentally separate from the societal domain. The transition from immediate unity through difference to mediated unity, the social freedom of 
Sittlichkeit, ${ }^{\text {xli }}$ is one which is meant to represent how the individual regards the state as a partner for fostering the development of their rational capacities in an effort to achieve self-realisation. In other words, from the perspective of mediated unity, the individual is not conceived of simply as an anonymous cog in the workings of a complex social machine, and nor is the individual conceived of as antagonistic to the state. Rather, the individual is conceived of as a bona fide self-determining and rationally self-reflexive agent who requires assistance from the state in an effort to realise their own autonomy.

Both the sublation of the concept of Being and the sublation of the concept of unity represent radical critiques of the respective original determinations of the two concepts, to the extent that Hegel aims to fundamentally overcome the original determinations. However, crucially, this is what distinguishes Hegel's sublation of common sense and makes it special: providing a critical ground for the commitments of common-sense realism and making explicit what ordinary consciousness had taken implicitly serves to speculatively vindicate common sense rather than find it to be the kind of orientation in thinking that needs to be radically overcome. For, Hegel thinks that the only way to properly conclude that the world is fundamentally intelligible and that it is a phenomenologically robust cognitive environment is by developing the intricate and nuanced arguments of speculative idealism to provide rational articulations of the various commitments of common-sense realism. As Hegel writes:

In daily life, says Herr Schulze, we presuppose that identity [of thinking and being, of concept and thing]; that it is presupposed in daily life means that it is not present in consciousness ... Just because that identity is presupposed in daily life, the ordinary consciousness posits the object always as an other relative to the subject ...; metaphysics brings this identity, which is for ordinary consciousness merely presupposed and unconsciousness, to consciousness. (On the Relation of Scepticism to Philosophy: 342)

If the arguments of this paper have been successful, then it seems that Hegel's relationship with common sense is more complicated and more interesting than either the long-standing reading of him as disdainful of common sense or the McDowellian reading of him as an ally of later-Wittgensteinian philosophical therapy. Hegel is certainly hostile to ordinary consciousness at some level, but we should ultimately see his critique of ordinary consciousness in terms of a nuanced philosophical vindication of common sense. 


\section{References}

Beiser, F. C. 1987. The Fate of Reason: German Philosophy from Kant to Fichte. Cambridge, MA: Harvard University Press.

--- 1998. 'German Romanticism', in E. Craig (ed.) The Routledge Encyclopaedia of Philosophy. London and New York: Routledge.

--- 2002. German Idealism: The Struggle against Subjectivism, 1781-1801. Cambridge, MA: Harvard University Press.

--- 2005. Hegel. New York \& London: Routledge.

Bristow, W. F. 2007. Hegel and the Transformation of Philosophical Critique. Oxford: Clarendon Press.

Bowman, B. 2013. Hegel and the Metaphysics of Absolute Negativity. Cambridge: Cambridge University Press.

Bubbio, P. D. 2016. 'The Reality of Religion in Hegel's Idealist Metaphysics'. Hegel Bulletin 27: 232-257.

Ferrini, C. 2009a. 'The Challenge of Reason: From Certainty to Truth', in K. R. Westphal (ed.) The Blackwell Guide to Hegel's Phenomenology of Spirit. Oxford: Blackwell.

--- 2009b. 'Reason Observing Nature', in K. R. Westphal (ed.) The Blackwell Guide to Hegel's Phenomenology of Spirit. Oxford: Blackwell.

Forster, M. 1989. Hegel and Scepticism. Cambridge, MA: Harvard University Press.

Franks, P. 2005. All or Nothing: Systematicity, Transcendental Arguments, and Scepticism in German Idealism. Cambridge, MA: Harvard University Press.

Friedman, M. 1996. 'Exorcising the Philosophical Tradition: Comments on John McDowell's Mind and World'. Philosophical Review 105: 427-67.

Hegel, G. W. F. 1970. Philosophy of Nature (Part Two of the Encyclopaedia of Philosophical Sciences). M. J. Petry (trans.) 3 vols. London: George Allen and Unwin.

--- 1975. Lectures on Aesthetics. T. M. Knox (trans.) 2 vols. Oxford: Oxford University Press.

-- 1977a. Phenomenology of Spirit. A. V. Miller (trans.) Oxford: Oxford University Press.

--- 1977b. The Difference Between Fichte's and Schelling's System of Philosophy. H. S. Harris \& W. Cerf (trans.) Albany, NY: State University of New York Press. 
--- 1985. 'On the Relation of Scepticism to Philosophy', in Between Kant and Hegel: Texts in the Development of Post-Kantian Idealism. G. di Giovanni and H. S. Harris (trans.) Albany: State University of New York Press.

--- 1991a. The Encyclopaedia Logic: Part 1 of the Encyclopaedia of Philosophical Sciences. T. F. Geraets, W. A. Suchting, and H. S Harris. (trans.) Indianapolis: Hackett.

--- 1991b. Elements of the Philosophy of Right. A. W. Wood (ed.) H. B. Nisbet (trans.) Cambridge: Cambridge University Press.

--- 1995. Lectures on the History of Philosophy. E. S. Haldane (trans.) Lincoln: University of Nebraska Press.

--- 2010. Science of Logic. G. di Giovanni (trans.) and (ed.) Cambridge: Cambridge University Press.

Heidemann, D. 2007. Der Begriff des Skeptizismus: Seine systematischen Formen, die pyrrhonische Skepsis und Hegels Herausforderung. Berlin and New York: de Gruyter.

Houlgate, S. 2006. The Opening of Hegel's Logic: From Being to Infinity. West Lafayette, IA: Purdue University Press.

Kaufmann, W. 1966. Hegel: Texts and Commentary. Garden City, NY: Anchor Books. Lear, J. 1988. Aristotle: The Desire to Understand. Cambridge: Cambridge University Press. Longuenesse, B. 2007. Hegel's Critique of Metaphysics. N. Simek (trans.) Cambridge: Cambridge University Press.

McDowell, J. 1994. Mind and World. Cambridge, MA: Harvard University Press.

Pringle-Pattison, A. S. 1897. Man's Place in the Cosmos. Edinburgh: William Blackwood.

Quante, M. 2004. 'Spekulative Philosophie als Therapie' in Hegels Erbe, H. von Christoph Halbig, M. Quante, and L. Siep (eds.) Suhrkamp Taschenbuch.

Stern, R. 1999. 'Going Beyond the Kantian Philosophy: On McDowell's Hegelian Critique of Kant'. European Journal of Philosophy 7: 247-269.

--- 2008. 'Hegel's Idealism', in F. C. Beiser (ed.) The Cambridge Companion to Hegel and Nineteenth-Century Philosophy. Cambridge: Cambridge University Press.

--- 2009. Hegelian Metaphysics. Oxford: Oxford University Press.

--- 2016. "Determination is Negation': The Adventures of a Doctrine from Spinoza to Hegel to the British Idealists'. Hegel Bulletin 37: 29-52.

Stone, A. 2005. 'Friedrich Schlegel, Romanticism, and the Re-enchantment of Nature'. Inquiry 48: 3-25. 
Pinkard, T. 1994. Hegel's Phenomenology: The Sociality of Reason. Cambridge: Cambridge University Press.

Pippin, R. B. 1989. Hegel's Idealism: The Satisfactions of Self-Consciousness. Cambridge: Cambridge University Press.

--- 1990. 'Hegel and Category Theory'. Review of Metaphysics 43: 839-848.

--- 1993. 'Hegel's Original Insight'. International Philosophical Quarterly 33: 285-95.

Westphal, K. R. 1989. Hegel's Epistemological Realism. Dordrecht: Kluwer.

--- 2003. Hegel's Epistemology: A Philosophical Introduction to Hegel's Phenomenology of Spirit.

Indianapolis: Hackett.

${ }^{\mathrm{i}}$ One might take Hegel's discussion of common sense throughout his various works to be a discussion of Scottish Common Sense Philosophy and its subsequent descendants, as opposed to a dialectical engagement with the non-technical sense of common sense. If so, then there seems reason to think that taking later Wittgenstein or John McDowell as the target is anachronistic. However, though there might be an issue over anachronism, Scottish Common Sense Philosophy and later Wittgensteinianism are interestingly related to one another. For an excellent discussion of Hegel and the descendants of Scottish Common Sense Philosophy, see Beiser (1987).

ii Throughout this paper, the terms 'common sense' and 'ordinary consciousness' will be used interchangeably.

iii Regarding Hegel and common sense in square conflict is not unique to either Anglophone receptions of Hegelianism or continental receptions of Hegelianism. Rather, both schools of thought have traditionally thought of Hegel and common sense in this manner.

iv J. McDowell, 1994: 112.

v While both passages from the Science of Logic indicate some of Hegel's most hostile arguments against common sense, I think it is very important not to lose sight of how that particular engagement with ordinary consciousness is contextualised against the background of Hegel's critique of Kant.

vi Cf. B. Bowman, 2013: 115. I position myself in the stream of the 'conceptual realist/revised metaphysical' interpretations of Hegel.

vii R. Stern, 1999: 260.

viii Ibid., p. 260.

${ }^{i x}$ I have discussed this issue in much greater detail in another paper. For further on Hegel's Aristotelianinspired conception of metaphysics, see Lear (1988), Beiser (2005), and Stern $(2008,2009)$.

${ }^{\mathrm{x}}$ It is important to note that Hegel regards ancient scepticism to be philosophically essential to deal with, and that he regards Cartesian and modern species of scepticism to ultimately be worthless. See, for example, passages such as the following from the Phenomenology of Spirit:

This path can accordingly be regarded as the path of doubt, or, more properly, as the path of despair, for what transpires on that path is not what is usually understood as doubt, namely, as an undermining of this or that alleged truth which is then followed by the disappearance of the doubt, and which in turn then returns to the former truth in such a way that what is at stake is taken to be exactly what it was in the first place ... For that reason, this self-consummating scepticism is also not the kind of scepticism with which a fervent zeal for truth and science imagines it has equipped itself so that it might be over and done with the matter. (PS: §78)

For works on Hegel's respective treatments of ancient scepticism and modern scepticism, see Forster (1989), Franks (2005), Bristow (2007) and Heidemann (2007).

xi McDowell, 1994: 113.

xii Michael Quante provides a very helpful framework for discussing Hegel and the therapeutic model of enquiry: Quante distinguishes between therapeutic and 'constructive' philosophy of various differing forms. In its narrowest sense, the conception of philosophy as therapeutic claims that the function of philosophy solely consists in curing misunderstandings that are engendered by philosophical mistakes. In a wider sense, the conception of philosophy as therapeutic claims that the function of philosophy consists in curing misunderstandings that are engendered by both the mistakes of philosophers and the mistakes of non-philosophers. With regard to 'constructive' philosophy, which Quante regards as equivalent to 
conceiving of philosophy as a problem-solving discipline, Quante draws four further distinctions: in the pejorative sense, this model of philosophy creates the problems that necessarily require therapeutic treatment by mistaking philosophical problematics for real/genuine problems; in its narrow sense, constructive philosophy provides solutions for real problems within common sense that pose genuine threats to the good life; in its wider sense, constructive philosophy goes further in wanting to provide a philosophical framework to support the assumptions of common sense, even when those assumptions are not the cause for various aporias; and in its revisionary sense, constructive philosophy aims to replace common sense, which it regards to be entirely bankrupt.

xiii F. C. Beiser, 2005: 164.

xiv Ibid., p. 165.

xv M. Friedman, 1996: 439-40.

xvi The German Romantics, as Beiser $(1998,2002)$ and Stone (2005) correctly note, regarded the modern era to have alienated man from the natural world and disenchanted nature by applying a very narrow and analytic form of enquiry. The Romantics believed that the Enlightenment had ultimately stripped nature and humanity off any beauty or real intrigue. As Fred Beiser writes, "[Romanticism] hoped to restore the beauty, magic and mystery of nature in the aftermath of the ravages of science and technology" (Beiser, 1998: 349). Furthermore, as Alison Stone writes, "[f]or Schlegel ... humans 'disenchant' (entzaubern) nature if they perceive it as not at all mysterious but completely intelligible by reason. Conversely, humans would 'enchant' (bezaubern) nature by perceiving it as partly mysterious, not fully rationally comprehensible" (Stone, 2005: 4). For Hegel, though, the Romantic appeal to mystery and rejection of reason is just as pernicious as narrow analysis. Therefore, Hegel's 'Romanticism' only consists in sharing the broad Romantic concern to account for nature in rich and enchanting ways. Contra the Romantics, Hegel believed that only a rich conceptualisation of nature will enable humanity to be re-enchanted with the natural world. Furthermore, Hegel should be seen as taking some distance from Romanticism, given his criticisms of certain ways of conceiving force, and also in how force is not as crucial for Hegel's philosophy of nature as it is for Schelling's philosophy of nature.

xvii See Westphal $(1989,2003)$.

xviii Cf. LHP I: 310; 351; III: 363-4; 367.

xix Cf. $E L$ : §42z: 85-6; $P N$ : §246z: 9-10; PM: §448.

${ }^{x x}$ P. D. Bubbio, 2016: 238-9.

${ }^{x x i} \mathrm{Cf}$. "In our ordinary way of thinking, the world is only an aggregate of finite existences ..." (PN: $\$ 247$, 16)

xxii Pippin, 1993: 288.

xxiii Pippin, 1990: 839.

xxiv B. Longuenesse, 2007: xvii.

${ }^{x x v}$ M. Gabriel, 2016: 188.

xxvi By this, I mean that the world is fundamentally intelligible and comprises of laws of nature, universals, and causal relations between substances.

xxvii One may ask here in which relation common sense and Sense-Certainty stand to each other - is SenseCertainty a manifestation of common sense? Or are they two different epistemological positions, whose relation is one of analogy? I would argue that Sense-Certainty and common sense are two different epistemological positions but are analogous in some way: what distinguishes the two positions from one another is how Sense-Certainty is pre-linguistic with its 'vocabulary' for grasping individual objects; what makes the two positions analogous in some way is how both Sense-Certainty and common sense fail in their own unique way to be sufficiently attuned to the necessary conditions that make certain kinds of cognitive experience possible.

xxviii For further on Hegel's transcendental concerns in Sense-Certainty, see Taylor (1972), Dulckeit (1986), Pippin (1989) and Pinkard (1994).

xxix R. B. Pippin, 1989: 117.

$x x x$ "....in this simplicity [Now] is indifferent to what happens in it; just as little as Night and Day are its being, just as much also is it Day and Night; it is not in the least affected by this its other-being. A simple thing of this kind which is through negation, which is neither This nor That, a not-This, and is with equal indifference This as well as That - such a thing we call a universal. So it is in fact the universal that is the true [content] of sense-certainty... The same will be the case with the other form of 'This', with 'Here'. 'Here' is e.g., the tree. If I turn round, this truth has vanished and is converted into its opposite: 'No tree is here, but a house instead'. 'Here' itself does not vanish; on the contrary, it abides constant in the vanishing of the house, the tree, etc., and is indifferently house or tree. Again, therefore, the 'This' shows itself to be a mediated simplicity, or a universality..." (PS: §96-98) 
xxxi By this, I mean being endowed with capacities that enable us to draw distinctions and similarities determinate negations - and relations between things - formal and informal inferences.

xxxii Hegel makes this especially clear in 'Perception', where he writes the following: "... if the many determinate properties were strictly indifferent to one another, if they were simply and solely self-related, they would not be determinate; for they are only determinate insofar as they differentiate themselves from one another, and relate themselves to others as to their opposites". (PS: $§ 114$.

xxxiii Cf. $S L$ : $12.33-4 ; 531$.

xxxiv See W. F. Bristow, 2007: 142, 150.

xxxv W. Kaufmann, 1966: 115-6.

xxxvi Such claims are also made by Hegel in the Phenomenology of Spirit. See, for example, the following passage from 'Observing Reason': "Observation, which kept [its biological categories] properly apart and believed that in them it had something firm and settled, sees principles overlapping one another, transitions and confusions developing; what it at first took to be absolutely separate, it sees combined with something else, and what it reckoned to be in combination, it sees apart and separate. So it is that observation which clings to passive, unbroken selfsameness of being, inevitably sees itself tormented just in its most general determinations - e.g. of what are the differentiae of an animal or a plant - by instances which rob it of every determination, invalidate the universality to which it has risen, and reduce it to an observation and description which is devoid of thought". (PS: §247)

For an excellent discussion of Hegel's views in 'Observing Reason', see Ferrini (2009a, 2009b).

xxxvii Cf. $S L: 21.101 ; 87,11.37 ; 472$; and $E L$ : $\S 87 Z$, $\S 91 Z$.

xxxviii In the words of Pringle-Pattison, Hegel is staunchly opposed to a view of Being in which all determinations are "devoured, like clouds before the sun, in the white light of the unica substantia" (MPC: 173).

xxxix Cf. $S L: 21.68-9 ; 59$.

${ }^{x l}$ See the following from Stephen Houlgate:

"For Parmenides... [t]rue being is thus purely affirmative with no trace of negation or indeed change in it; it is thus 'uncreated and imperishable'. This conception of being as purely affirmative continues to cast its shadow over subsequent philosophy right up to the modern period. It is to be seen, for example, in Spinoza's assertion that 'the definition of any thing affirms, and does not deny, the thing's essence,'... [But] According to Hegel's account, the category of being proves to harbor within itself the moment of negation in several forms: the concept of reality entails negation in the form of determinacy and difference; being something entails negation in the form of otherness and finitude; and infinite being also contains negation insofar as it lives in and through self-negating, finite beings". (S. Houlgate, 2006: 43-4)

See also Stern (2016).

xli See $P R: \$ \S 157-8,181$. 